\title{
ANALISIS PENGARUH KARAKTERISTIK KOMITE AUDIT DAN STRUKTUR KEPEMILIKAN TERHADAP MANAJEMEN LABA PADA PERUSAHAAN YANG TERDAFTAR DI BURSA EFEK INDONESIA
}

\author{
Hendi* dan Septi Lisniati* \\ *Program Studi Akuntansi, Fakultas Ekonomi \\ Universitas Internasional Batam \\ Email: hendi.chan@uib.ac.id;liliteo95@gmail.com
}

\begin{abstract}
This research is conducted to determine the impact of audit committee characteristics and ownership structures on earnings management of companies listed on Indonesian Stock Exchange (IDX). This research used 324 companies listed on IDX in the period 2011-2015 as the sample. The results of this study indicate that institutional ownership, firm size, return on asset, and operating cash flow show the significant impact on earnings management in both positive and negative ways. On other hand, the results also indicate that the independence, diligence, and size of audit committee, foreign ownership, managerial ownership, governmental ownership, individual ownership, and leverage are not able to affect earnings management activity significantly.
\end{abstract}

Keywords: audit committee characteristics, ownership structures, earnings management

\section{PENDAHULUAN}

Pertumbuhan ekonomi global yang semakin lamban tidak menyebabkan seluruh perusahaan menunjukkan kinerja yang buruk. Masih ada perusahaan yang mampu menunjukkan kinerja yang memuaskan. Kinerja perusahaan yang ditunjukkan dalam laporan keuangan belum tentu merefleksikan kondisi perusahaan yang sebenarnya. Keadaan ini dapat disebabkan oleh kemampuan manajemen dalam mengelola laba (Chandrasegaram, Rahimansa, Rahman, Abdullah, \& Mat, 2013).

Pengelolaan laba atau manajemen laba berhubungan erat dengan teori keagenan karena adanya pemisahan peran antara manajemen dan pemegang saham sehingga konflik kepentingan dapat terjadi (Yusof, 2010). Manajemen laba juga dapat terjadi karena lemahnya penerapan tata kelola di perusahaan. Blue Ribbon Committee (1999) menjelaskan bahwa komite audit merupakan mekanisme tata kelola perusahaan yang paling penting karena bertanggung jawab untuk memastikan bahwa kualitas laporan keuangan yang dihasilkan pada perusahaan tinggi. Pemilihan struktur kepemilikan yang sesuai dengan kebutuhan perusahaan juga dianggap penting karena telah terbukti mampu untuk mengurangi praktik manajemen laba pada perusahaan (Adebiyi \& Olowookere, 2016).

\section{KAJIAN LITERATUR PENGEMBANGAN HIPOTESIS \\ Manajemen Laba}

Manajemen laba adalah intervensi yang disengaja dari pihak manajemen pada proses pelaporan keuangan internal perusahaan untuk mencapai tujuan pribadi (Schipper, 1989). Menurut Watts dan Zimmerman (1990), ada beberapa hal yang dapat memotivasi tindakan manajemen laba, antara lain motivasi program bonus, motivasi politis, motivasi perpajakan, initial public offering (IPO), motivasi pergantian direktur, dan motivasi perjanjian utang.

Banyak cara yang dapat dilakukan oleh manajemen pada praktik manajemen laba, antara lain menata transaksi laba dan 
pendapatan, merubah prosedur akuntansi, dan manajemen akrual (McNichols, 1988; Schipper 1989). Akrual diartikan sebagai perbedaan antara laba dan arus kas dari kegiatan operasi. Akrual dapat dibagi menjadi dua, yaitu non-discretionary accruals dan discretionary accruals. Nondiscretionary accruals merupakan penyesuaian pada arus kas yang masih mengikuti kaidah akuntansi yang berlaku, sedangkan discretionary accruals adalah penyesuaian akuntansi pada arus kas sesuai dengan kebijakan manajemen (Rao \& Dandale, 2008).

\section{Model Penelitian Terdahulu}

Berbagai praktik yang mengarah pada aktivitas manajemen laba mulai diteliti sejak awal abad ke 20 (Hepworth, 1953). Sekitar tahun 1970 hingga awal 1980, banyak peneliti yang menemukan bahwa manajer dapat membuat kebijakan melalui pemilihan metode akuntansi, seperti memilih metode depresiasi, melakukan penilaian inventori, dan lain-lain yang berdampak pada kegiatan manipulasi laba (Watts \& Zimmerman; Sun \& Rath, 2010). Sejak tahun 1980 hingga 1990, penelitian manajemen laba berpusat pada estimasi akrual (Healy, 1985; Jones, 1991). Memasuki abad ke 21, penelitian mulai dipusatkan untuk mengeksplorasi pemahaman tentang pengaruh tata kelola perusahaan terhadap manajemen laba.

Chtourou, Bedard, dan Courteau (2001) melakukan observasi terhadap 100 perusahaan di Amerika Serikat pada tahun 1996. Independensi komite audit, kemampuan komite audit, dan aktivitas komite audit digunakan sebagai variabel independen. Variabel lain seperti karakteristik dewan, agen, big 6, blok, dan ukuran perusahaan juga diikutsertakan dalam penelitian ini.

Davidson et al. (2005) memusatkan penelitian pada hubungan antara manajemen laba dengan struktur internal tata kelola perusahaan. Sampel yang digunakan berupa 434 perusahaan di Australia pada tahun 2000. Variabel independen yang diuji adalah independensi dewan, pemisahan dewan, independensi komite audit, rapat komite audit, ukuran komite, fungsi auditor internal, dan big five. Selain variabel independen di atas, penelitian ini juga menggunakan variabel kontrol seperti pemegang saham mayoritas, leverage, modifikasi absolut pada laba bersih, ukuran perusahaan, laba, rasio nilai pasar terhadap nilai buku, dan extreme performance.

Penelitian lain dilakukan oleh Saleh et al (2007) di Malaysia untuk menguji pengaruh variabel independen berupa aktivitas komite audit, ukuran komite audit, pengetahuan komite audit, dan independensi komite audit terhadap manajemen laba. Sampel yang diteliti pada penelitian ini diambil dari laporan keuangan 548 perusahaan pada tahun 2001 di Bursa Malaysia.

Berbeda dengan penelitian sebelumnya, Li, Liu, dan Eddie (2011) mengambil struktur kepemilikan sebagai variabel independen untuk menguji tingkat manajemen laba pada 136 perusahaan yang terdaftar di Shanghai Stock Exchange. Variabel independen yang diuji antara lain kepemilikan negara, kepemilikan legal, kepemilikan asing, dan kepemilikan individu.

Penelitian selanjutnya dilakukan oleh Hassan dan Ahmed (2012) dengan mengambil sampel berupa perusahaanperusahaan yang bergerak di bidang makanan dan minuman di Nigeria. Penelitian ini dibuat untuk menguji pengaruh struktur kepemilikan terhadap manajemen laba. Adapun variabel independen seperti kepemilikan institusi, kepemilikan manajerial, konsentrasi kepemilikan, dan kepemilikan keluarga, serta variabel kontrol berupa ukuran perusahaan digunakan pada penelitian ini.

$$
\text { Aygun et al. }
$$
mengembangkan penelitian dengan menambahkan variabel kepemilikan manajerial, ukuran dewan, arus kas dari kegiatan operasi, dan tingkat pengembalian aset. Sampel yang diambil berupa 
perusahaan yang terdaftar di Istanbul Stock Exchange dalam rentang waktu 2009 sampai 2012.

Merujuk pada penelitian-penelitian sebelumnya, maka rumusan hipotesis yang akan diuji adalah sebagai berikut:

H1: Independensi komite audit berpengaruh signifikan negatif terhadap manajemen laba.

H2: Keahlian komite audit berpengaruh signifikan negatif terhadap manajemen laba.

H3: Kerajinan komite audit berpengaruh signifikan negatif terhadap manajemen laba.

H4: Ukuran komite audit berpengaruh signifikan negatif terhadap manajemen laba.

H5: Kepemilikan asing berpengaruh signifikan positif terhadap manajemen laba.

H6: Kepemilikan institusi berpengaruh signifikan negatif terhadap manajemen laba.

H7: Kepemilikan manajerial berpengaruh signifikan positif terhadap manajemen laba.

H8: Kepemilikan pemerintah berpengaruh signifikan positif terhadap manajemen laba.

H9: Kepemilikan individu berpengaruh signifikan positif terhadap manajemen laba

\section{METODOLOGI PENELITIAN}

Penelitian ini dikategorikan ke dalam penelitian dasar dan hanya bersifat mengatasi masalah secara teoritis, tetapi tidak berpengaruh secara langsung dalam penentuan kebijakan, kinerja, atau tindakan. (Indriantoro \& Supomo, 2013). Objek penelitian yang diambil merupakan perusahaan yang terdaftar di BEI dari tahun 2011 hingga 2015.

Sampel yang digunakan adalah laporan tahunan yang terdaftar di BEI. Metode pemilihan sampel yang digunakan pada penelitian ini merupakan purposive sampling dengan kriteria tertentu yang telah ditetapkan sebagai berikut:
1. Perusahaan yang menerbitkan laporan tahunan yang telah diaudit dan terdaftar di BEI dari tahun 2011 sampai dengan tahun 2015.

2. Perusahaan yang menerbitkan laporan tahunan dan mengungkapkan laporan tata kelola yang menyajikan independensi, keahlian, jumlah rapat, dan jumlah komite audit.

3. Perusahaan yang menerbitkan laporan keuangan yang menyajikan jumlah piutang usaha, aset, utang, penjualan, laba bersih, arus kas dari kegiatan operasi, aset tetap kotor, dan modal saham.

\section{Variabel Dependen}

Manajemen laba merupakan variabel dependen yang diteliti pada penelitian ini. Menurut Bagheri, Emamgholipur, Bagheri, dan Rekabdarkolaei (2013), manajemen laba dapat dideteksi dengan menggunakan skala rasio dan perhitungan modified Jones model melalui cara sebagai berikut:

1. Mencari Jumlah Akrual (TACC)

TACC dapat dihitung dengan cara sebagai berikut:

TACC = laba bersih - arus kas kegiatan operasi

2. Mencari Angka Koefisien

Uji regresi dengan perangkat lunak statistik harus dilakukan untuk memperkirakan koefisien agar dapat mencari angka non-discretionary accruals (NDACC).

$$
\begin{aligned}
& \frac{\mathrm{TACC}}{\mathrm{At}-1}=\alpha_{1}\left(\frac{1}{\left(\frac{A t-1}{P P E}\right.}\right)+\alpha_{2} \\
& \left(\frac{\triangle R E V-\triangle R E C}{A t-1}\right)+\alpha_{3}\left(\frac{P t-1}{A t-1}\right)
\end{aligned}
$$

\section{Variabel Independen dan Variabel Kontrol}

Variabel independen dan variabel kontrol yang diteliti yang telah diteliti sebelumnya dan diduga merupakan faktor faktor yang mempengaruhi manajemen laba. Dalam menguji hipotesis yang 
Global Financial Accounting Journal, Vol. 4, No. 1, April 2020 ISSN: 2655-836X

diajukan, dalam penelitian ini menggunakan 9 (sembilan) variabel independen dan 4 (empat) variabel dependen. Berikut adalah daftar variabel independen dan variabel kontrol yang digunakan: 
Tabel 1

Variabel Independen dan Variabel Kontrol

\begin{tabular}{|c|c|c|}
\hline No & Nama Variabel & Pengukuran \\
\hline \multicolumn{3}{|c|}{ Variabel Independen } \\
\hline 1 & Independensi Komite Audit & $\begin{array}{l}\text { IKA = Proporsi komite audit independen terhadap jumlah komite } \\
\text { audit (Nelwan \&Tansuria, 2011) }\end{array}$ \\
\hline 2 & Keahlian Komite Audit & $\begin{array}{l}\text { KA = Proporsi komite audit berkeahlian keuangan/akuntansi } \\
\text { terhadap jumlah komite audit (Thoopsamut \& Jaingkengit, 2008) }\end{array}$ \\
\hline 3 & Kerajinan Komite Audit & $\begin{array}{l}\text { KERKA = Jumlah rapat komite audit dalam setahun (Soliman \& } \\
\text { Ragab, 2014) }\end{array}$ \\
\hline 4 & Ukuran Komite Audit & $\begin{array}{l}\text { UKA = Jumlah individu di dalam susunan komite audit (Ayemere } \\
\& \text { Elijah, 2015) }\end{array}$ \\
\hline 5 & Kepemilikan Asing & $\begin{array}{l}\text { KAS = Proporsi jumlah saham yang dimiliki oleh pemegang } \\
\text { saham asing terhadap jumlah saham yang beredar (Ali et al., 2008) }\end{array}$ \\
\hline 6 & Kepemilikikan Institusi & $\begin{array}{l}\text { KI = Proporsi jumlah saham yang dimiliki oleh institusi } \\
\text { terhadap jumlah saham yang beredar (Hassan \& Ahmed, 2012) }\end{array}$ \\
\hline 7 & Kepemilikan Manajerial & $\begin{array}{l}\text { KM = Proporsi jumlah saham yang dimiliki oleh direksi terhadap } \\
\text { jumlah saham yang beredar (Guo \& Ma, 2015) }\end{array}$ \\
\hline 8 & Kepemilikan Pemerintah & $\begin{array}{l}\mathrm{KP}=\text { Proporsi jumlah saham yang dimiliki oleh pemerintah } \\
\text { terhadap jumlah saham yang beredar (Guo \& Ma, 2015) }\end{array}$ \\
\hline 9 & Kepemilikan Individu & $\begin{array}{l}\text { KIND = Proporsi jumlah saham yang dimiliki oleh individu }(<5 \%) \\
\text { terhadap jumlah saham yang beredar (Isenmila \& Elijah, 2012) }\end{array}$ \\
\hline \multicolumn{3}{|c|}{ Variabel Kontrol } \\
\hline 1 & Ukuran Perusahaan & $\begin{array}{l}\text { UP }=\text { Nilai logaritma dari jumlah aset akhir tahun (Alkdai \& } \\
\text { Hanefah, 2012) }\end{array}$ \\
\hline 2 & Leverage & $\begin{array}{l}\text { LEV = Proporsi jumlah utang akhir tahun terhadap aset akhir } \\
\text { tahun (Bagheri et al., 2013) }\end{array}$ \\
\hline 3 & Tingkat Pengembalian Aset & $\begin{array}{l}\text { ROA = Proporsi jumlah laba akhir tahun terhadap aset akhir tahun } \\
\text { (Aygun et al., 2014) }\end{array}$ \\
\hline 4 & Arus Kas Kegiatan Operasi & $\begin{array}{l}\text { OCF = Proporsi arus kas dari kegiatan operasi terhadap jumlah } \\
\text { aset awal tahun (Alzoubi, 2014) }\end{array}$ \\
\hline
\end{tabular}

Sumber: Data penelitian diolah, 2019

\section{HASIL PENELITIAN}

Jumlah perusahaan yang terdaftar di BEI sampai dengan tahun 2015 adalah 523 perusahaan. Terdapat 95 perusahaan yang terdaftar setelah tahun 2011 sehingga perusahaan yang dapat diambil sebagai sampel adalah 428 perusahaan. Dari 428 perusahaan hanya 324 perusahaan yang dapat dijadikan sampel karena tidak seluruh perusahaan menyajikan laporan keuangan dengan lengkap. Masing-masing perusahaan diobservasi selama 5 (lima) tahun dan data yang diuji berjumlah 1.620, tetapi setelah dilakukan uji outlier terdapat 257 data yang menyimpang terlalu jauh sehingga data yang tersisa untuk uji outlier adalah 1.363 data. Hasil dari statistik deskriptif penelitian setelah dilakukan uji outlier dapat dilihat pada Tabel 2 di bawah ini.

\section{Uji Chow (Pooled Least Square vs Fixed Effect Model)}

Uji Chow digunakan untuk memilih antara metode pooled least square dan fixed effect model. Kriteria yang digunakan dalam pemilihan metode adalah nilai probabilitas pada cross section chi-square pada hasil uji Chow. Apabila nilai probabilitas di atas 0,05 maka akan dipilih metode pooled least square. Apabila nilai probabilitas di bawah 0,05, maka akan dilanjutkan dengan uji Hausman. Hasil Uji Chow pada Tabel 3 menunjukkan keperluan untuk dilanjutkan dengan Uji Hausman.

\section{Uji Hausman (Fixed Effect Model vs Radom Effect Model)}

Uji Hausman digunakan untuk memilih metode antara fixed effect model dan random effect model. Kriteria yang 
Tabel 2

Hasil Uji Statistik Deskriptif

\begin{tabular}{|c|c|c|c|c|}
\hline \multirow{2}{*}{ Keterangan } & \multicolumn{4}{|c|}{ Statistik Deskriptif } \\
\hline & Minimum & Maksimum & Rata-Rata & Std. Deviasi \\
\hline Manajemen Laba & $-4,72111$ & 1,47084 & $-0,07324$ & 0,22606 \\
\hline Independensi Komite Audit & 0,75000 & 1,00000 & 0,99534 & 0,03349 \\
\hline Keahlian Komite Audit & 0,00000 & 1,00000 & 0,68937 & 0,25768 \\
\hline Kerajinan Komite Audit & 0,00000 & 36,00000 & 6,59868 & 4,53437 \\
\hline Ukuran Komite Audit & 2,00000 & 5,00000 & 3,10345 & 0,44722 \\
\hline Kepemilikan Asing & 0,00000 & 0,99088 & 0,28947 & 0,31159 \\
\hline Kepemilikan Institusi & 0,00000 & 0,99997 & 0,69051 & 0,19261 \\
\hline Kepemilikan Manajerial & 0,00000 & 0,17970 & 0,00541 & 0,02169 \\
\hline Kepemilikan Pemerintah & 0,00000 & 0,43770 & 0,00371 & 0,02897 \\
\hline Kepemilikan Individu & 0,00000 & 0,54840 & 0,05923 & 0,12399 \\
\hline Ukuran Perusahaan (milyar) & 16 & 855.000 & 2.000 & 0,76076 \\
\hline Leverage & 0,00025 & 2,28145 & 0,51284 & 0,25636 \\
\hline Tingkat Pengembalian Aset & $-0,61591$ & 0,64312 & 0,47888 & 0,08976 \\
\hline Arus Kas Kegiatan Operasi & $-0,41415$ & 0,54698 & 0,06394 & 0,11806 \\
\hline N (jumlah data) & 1363 & 1363 & 1363 & 1363 \\
\hline
\end{tabular}

Sumber: Data sekunder diolah, 2019.

digunakan dalam pemilihan metode ini adalah nilai probabilitas pada cross section random hasil uji Hausman. Apabila nilai probabilitas diatas nilai $\alpha$, yaitu 0,05 maka akan digunakan metode random effect model. Apabila nilai probabilitas di bawah 0,05, maka akan dipilih metode fixed effect model. Hasil Uji Hausman pada Tabel 4 menunjukkan bahwa metode fixed effect model yang akan digunakan.

Tabel 3

Hasil Uji Chow

\begin{tabular}{|c|c|c|}
\hline Effect Test & Prob. & Kesimpulan \\
\hline $\begin{array}{c}\text { Cross Section } \\
\text { Chi-square }\end{array}$ & 0,0000 & $\begin{array}{c}\text { Fixed Effect } \\
\text { Model }\end{array}$ \\
\hline
\end{tabular}

Sumber: Data sekunder diolah, 2019.

Tabel 4

Hasil Uji Hausman

\begin{tabular}{|c|c|c|}
\hline Effect Test & Prob. & Kesimpulan \\
\hline $\begin{array}{c}\text { Cross Section } \\
\text { Random }\end{array}$ & 0,0198 & $\begin{array}{c}\text { Fixed Effect } \\
\text { Model }\end{array}$ \\
\hline
\end{tabular}

Sumber: Data sekunder diolah, 2019.

\section{Uji F}

Hasil uji F dilakukan untuk menguji pengaruh variabel independen dan kontrol terhadap variabel dependen secara simultan dengan menguji hubungan linieritas antara variabel independen dan kontrol terhadap variabel dependen. Jika nilai signifikansinya kurang dari $\alpha(0,05)$, maka variabel independen dan kontrol secara simultan berpengaruh terhadap variabel dependen dan model yang digunakan telah sesuai. Sebaliknya, apabila nilai signifikansinya kurang dari $\alpha(0,05)$, maka

Tabel 5

Hasil Uji F

\begin{tabular}{|c|c|c|}
\hline Variabel Dependen & Sig. & Kesimpulan \\
\hline Manajemen Laba & 0,0000 & Signifikan \\
\hline
\end{tabular}

Sumber: Data sekunder diolah, 2019.

dapat disimpulkan bahwa variabel independen dan kontrol secara simultan tidak berpengaruh terhadap variabel dependen.

Hasil uji $F$ di atas menunjukkan nilai manajemen laba dengan tingkat signifikansi kurang dari 0,05. Hal ini menggambarkan bahwa variabel independen secara simultan memiliki pengaruh yang signifikan terhadap manajemen laba. Kesimpulan yang diperoleh adalah bahwa model regresi ini dapat digunakan untuk memprediksi faktor yang mempengaruhi manajemen laba. 
Tabel 6

Hasil Uji $t$

\begin{tabular}{|l|r|r|l|l|}
\hline \multicolumn{1}{|c|}{ Variabel } & \multicolumn{1}{c|}{ t } & \multicolumn{1}{c|}{ Prob } & \multicolumn{1}{c|}{ Keterangan } & \multicolumn{1}{c|}{ Hipotesis } \\
\hline Independensi Komite Audit & 0,60876 & 0,5428 & Tidak signifikan & Tidak terbukti \\
\hline Keahlian Komite Audit & $-1,70710$ & 0,0881 & Tidak signifikan & Tidak terbukti \\
\hline Kerajinan Komite Audit & $-0,60261$ & 0,5469 & Tidak signifikan & Tidak terbukti \\
\hline Ukuran Komite Audit & $-1,54906$ & 0,1217 & Tidak signifikan & Tidak terbukti \\
\hline Kepemilikan Asing & 1,36729 & 0,1718 & Tidak signifikan & Tidak terbukti \\
\hline Kepemilikan Institusi & 2,21358 & 0,0271 & Signifikan positif & Tidak terbukti \\
\hline Kepemilikan Manajerial & 1,06937 & 0,2851 & Tidak signifikan & Tidak terbukti \\
\hline Kepemilikan Pemerintah & 0,74631 & 0,4556 & Tidak signifikan & Tidak terbukti \\
\hline Kepemilikan Individu & 1,54492 & 0,1226 & Tidak signifikan & Tidak terbukti \\
\hline Ukuran Perusahaan & 15,50055 & 0,0000 & Signifikan positif & - \\
\hline Leverage & $-0,09062$ & 0,9278 & Tidak signifikan & - \\
\hline Tingkat Pengembalian Aset & 14,42362 & 0,0000 & Signifikan positif & - \\
\hline Arus Kas Kegiatan Operasi & $-17,93552$ & 0,0000 & Signifikan negatif & - \\
\hline C & $-8,94569$ & 0,0000 & & \\
\hline Sumber: Data sekunder dif & & & \\
\end{tabular}

Sumber: Data sekunder diolah, 2019.

\section{Uji t}

Hasil uji t dalam fixed effect model disajikan pada Tabel 6. Hasil uji regresi di atas menunjukkan bahwa variabel independensi komite audit tidak berpengaruh signifikan terhadap manajemen laba. Yusof (2010) yang melakukan penelitian di Malaysia menyatakan bahwa anggota komite audit dari luar cenderung sulit mengakses data keuangan sehingga tidak mampu melaksanakan fungsi pengawasan secara optimal. Hal yang sama juga terjadi di Indonesia. Pernyataan piagam komite audit pada bagian wewenang komite audit berupa komite audit dapat mengakses data yang diperlukan tidak menjamin seluruh perusahaan secara praktik mengizinkan komite audit independen untuk mendapatkan informasi yang diperlukan dalam pelaksanaan tugas komite audit sehingga gagal dalam menekan praktik manajemen laba. Hasil ini tidak sesuai dengan $\mathrm{H}_{1}$ tetapi konsisten dengan penelitian yang dilakukan oleh Chtourou et al. (2001), Lin et al. (2009), Yusof (2010), Habbash (2011), dan Prayogo et al. (2015).

Tabel 6 di atas menunjukkan bahwa keahlian komite audit tidak berpengaruh signifikan terhadap manajemen laba. Saleh et al. (2007) berpendapat bahwa fungsi pengawasan terhadap proses pelaporan keuangan bukan terletak pada keahlian komite audit, melainkan pada aktivitasaktivitas yang dilakukan oleh komite audit dalam melaksanakan tugas yang diberikan. Hasil ini tidak sesuai dengan $\mathrm{H}_{2}$, namun sejalan dengan penelitian yang dilakukan oleh Saleh et al. (2007), Thoopsamut dan Jaikengit (2008), serta Lin et al. (2009).

Variabel independen kerajinan komite audit juga tidak menunjukkan pengaruh yang signifikan terhadap manajemen laba. Menon dan Williams (1994) berpendapat bahwa jumlah rapat yang diadakan oleh komite audit tidak menjamin hal yang dibahas berhubungan dengan fungsi pengawasan sehingga tidak berpengaruh terhadap angka manajemen laba pada suatu perusahaan. Hasil ini bertentangan dengan $\mathrm{H}_{3}$, namun sejalan dengan penelitian yang dilakukan oleh Saleh et al. (2012), Thoopsamut dan Jaikengit (2008), Prayogo et al. (2013), dan Chandrasegaram et al. (2013).

Hasil uji regresi juga menunjukkan bahwa ukuran komite audit tidak mempengaruhi manajemen laba secara signifikan. Menurut Prayogo et al. (2013), struktur keanggotaan komite audit di Indonesia tidak sepenuhnya diterapkan sesuai ketentuan yang berlaku karena hanya dianggap sebagai bagian dari kepatuhan terhadap peraturan yang ada. Hal ini menyebabkan komite audit cenderung tidak melaksanakan fungsi pengawasan secara 
efektif. Hasil ini bertentangan dengan $\mathrm{H}_{4}$, tetapi sejalan dengan penelitian yang dilakukan oleh Saleh et al. (2007), Alkdai dan Hanefah (2012), Prayogo et al. (2013), Chandrasegaram et al. (2013), serta Soliman dan Ragab (2014).

Dapat dilihat dari Tabel 6, variabel independen kepemilikan asing tidak menunjukkan pengaruh signifikan terhadap manajemen laba. Li et al. (2011) yang melakukan penelitian di China mengenai jenis saham dan manajemen laba berpendapat bahwa kurangnya partisipasi pihak asing dalam pelaksanaan tata kelola perusahaan, perbedaan regulasi, dan kebegaraman budaya adalah faktor-faktor yang mempengaruhi ketidakmampuan pemegang saham asing dalam pelaksanaan fungsi pengawasan sehingga tidak mempengaruhi angka manajemen laba pada perusahaan dengan mayoritas pemegang saham asing. Hasil ini tidak sejalan dengan $\mathrm{H}_{5}$, tetapi konsisten dengan penelitian Lin et al. (2009) dan Li et al. (2011).

Variabel independen kepemilikan institusi merupakan satu-satunya variabel independen yang berpengaruh signifikan positif terhadap manajemen laba. Menurut Bushee (1998), sebagian pemegang saham institusi cenderung berpusat terhadap laba masa kini untuk menentukan harga saham. Keadaan ini membuat institusi tertentu mengabaikan fungsi pengawasan sehingga manajemen dapat bertindak lebih leluasa dalam pengelolaan laba. Hasil ini tidak sesuai dengan $\mathrm{H}_{6}$, namun sejalan dengan penelitian Alves (2011), Emamgholipur et al. (2013), dan Alaryan (2015).

Variabel selanjutnya dari struktur kepemilikan yaitu kepemilikan manajerial menunjukkan hasil yang tidak signifikan terhadap manajemen laba. Warfield et al. (1995) menyatakan bahwa fungsi pengawasan dari kepemilikan manajerial tidak selalu berpengaruh dalam mengurangi konflik keagenan. Hal ini dapat terjadi ketika komite yang dibentuk untuk melakukan fungsi pengawasan telah bekerja dengan baik dalam rangka mencapai tujuan pemegang saham. Hasil ini tidak sesuai dengan $\mathrm{H}_{7}$, namun sejalan dengan hasil penelitian Habbash (2011), Gulzar dan Wang (2011), serta Greco (2012).

Kepemilikan pemerintah juga tidak mampu mempengaruhi manajemen laba secara signifikan. Guo dan Ma (2015) berpendapat bahwa kepemilikan pemerintah tidak ada hubungannya dengan praktik manajemen laba. Manajer yang bekerja di perusahaan milik pemerintah umumnya menerima kompensasi berupa kenaikan jabatan politik dan remunerasi, bukan kompensasi bonus dari persentase laba seperti perusahaan komersial. Hal ini jelas membuktikan bahwa fungsi pengawasan dari pemerintah tidak menjadi tolak ukur keberadaan praktik manajemen laba pada suatu perusahaan. Hasil ini tidak sejalan dengan $\mathrm{H}_{8}$ yang ada, namun konsisten dengan penelitian Niri et al. (2014), serta Guo dan Ma (2015).

Variabel struktur kepemilikan yang terakhir yaitu kepemilikan individu menunjukkan hasil yang sama dengan variabel kepemilikan lain. Tabel 6 diatas menunjukkan bahwa kepemilikan individu tidak berpengaruh signifikan terhadap manajemen laba. Menurut Al-Fayoumi, Abuzayed, dan Alexander (2006), individu umumnya hanya menginginkan pengembalian yang tinggi dari investasi yang dipilih tanpa mempertimbangkan faktor-faktor lain. Keadaan ini menyebabkan individu jarang ikut campur dalam pengelolaan perusahaan sehingga fungsi pengawasan terhadap manajemen tidak berjalan dengan baik. Hasil ini tidak sejalan dengan $\mathrm{H}_{9}$, namun sesuai dengan hasil uji regresi yang dilakukan oleh AlFayoumi et al. (2006).

\section{Uji Koefisien Determinasi $\left(\mathbf{R}^{\mathbf{2}}\right)$}

Hasil uji koefisien determinasi $\left(\mathrm{R}^{2}\right)$ disajikan pada Tabel 7 di bawah. Hasil uji koefisien determinasi $\left(\mathrm{R}^{2}\right)$ menunjukkan angka adjusted $\mathrm{R}$ Square sebesar 0,495813 atau $49,58 \%$. 
Tabel 7

Hasil Uji Koefisien Determinasi $\left(R^{2}\right)$

\begin{tabular}{|c|c|}
\hline Variabel Dependen & Adjusted R Square \\
\hline Manajemen Laba & 0,495813 \\
\hline \multicolumn{2}{|c|}{ Sumber: Data sekunder diolah, 2019.}
\end{tabular}

Hal ini mengindikasikan bahwa $49,58 \%$ variabel dependen berupa manajemen laba dapat dijelaskan oleh variabel independensi komite audit, keahlian komite audit, kerajinan komite audit, ukuran komite audit, kepemilikan asing, kepemilikan institusi, kepemilikan manajerial, kepemilikan pemerintah, kepemilikan individu, ukuran perusahaan, leverage, tingkat pengembalian aset, dan arus kas dari kegiatan operasi.

\section{KESIMPULAN}

Penelitian ini bertujuan untuk mengetahui pengaruh variabel independen yaitu independensi komite audit, keahlian komite audit, kerajinan komite audit, ukuran komite audit, kepemilikan asing, kepemilikan institusi, kepemilikan manajerial, dan kepemilikan individu, serta variabel kontrol berupa ukuran perusahaan, leverage, tingkat pengembalian aset, dan arus kas kegiatan operasi terhadap manajemen laba.

Variabel kepemilikan institusi berpengaruh signifikan positif terhadap manajemen laba. Hal ini berarti semakin tinggi kepemilikan institusi dalam suatu perusahaan, maka praktik manajemen laba akan meningkat. Hasil ini tidak sesuai dengan hipotesis penelitian, namun didukung oleh penelitian Alves (2011), Emamgholipur et al. (2013), dan Alaryan (2015). Ukuran perusahaan juga menunjukkan pengaruh signifikan positif terhadap manajemen laba. Perusahaan yang besar memiliki kecenderungan untuk menata laba untuk menarik perhatian pasar dan memenuhi harapan para pengamat keuangan (Barton \& Simko, 2002). Begitu pula dengan variabel tingkat pengembalian aset yang diukur dengan Return of Asset (ROA), dimana semakin tinggi angka ROA, maka praktik manajemen laba pada perusahaan akan semakin besar. Hasil ini selaras dengan penemuan pada penelitian Yusof (2010), Salihi dan Jibril (2015), serta Alzoubi (2015).

Variabel kontrol arus kas kegiatan operasi merupakan satu-satunya variabel yang berpengaruh signifikan negatif terhadap manajemen laba. Hal ini membuktikan bahwa perusahaan dengan arus kas dari kegiatan operasi yang besar tidak perlu lagi melakukan manajemen laba karena telah mampu menunjukkan kinerja perusahaan yang baik (Jiang, et al., 2008). Hasil ini sejalan dengan penelitian yang dilakukan oleh Yang et al. (2008), Alves (2011), serta Soliman dan Ragab (2014).

Independensi komite audit, keahlian komite audit, kerajinan komite audit, ukuran komite audit, kepemilikan asing, kepemilikan manajerial, kepemilikan pemerintah, kepemilikan indvidu dan leverage tidak berpengaruh signifikan terhadap manajemen laba. Variabel komite audit tidak dapat mempengaruhi manajemen laba karena peraturan yang mengatur tentang komite audit tidak menyebutkan secara jelas keahlian akuntansi dan atau keuangan yang harus dimiliki oleh anggota komite audit dan halhal yang harus dibahas pada saat pertemuan komite audit dilakukan. Sebagai tambahan, independensi yang diukur dengan syaratsyarat yang tertera pada peraturan BAPEPAM-LK tidak dapat menjamin bahwa anggota komite audit bertindak independen dalam menyatakan sikap dan pendapat (Mutiawero, 2014). Variabel dari struktur kepemilikan juga tidak dapat mempengaruhi manajemen laba karena kecilnya partisipasi dan peran dari pihak asing, manajemen, pemerintah, dan individu di perusahaan yang terdaftar di BEI. Begitu juga dengan leverage, dimana variabel kontrol ini hanya dapat berpengaruh signifikan terhadap tingkat manajemen laba apabila pihak pemberi pinjaman memberikan pengawasan yang ketat dan terstruktur terhadap perusahaan (Nuswantara, 2004). 
Penelitian ini memiliki beberapa keterbatasan antara lain:

1. Banyak perusahaan yang terdaftar di BEI yang tidak menerbitkan data laporan keuangan secara lengkap berturut-turut lima tahun dari tahun 2011 sampai 2015 sehingga jumlah sampel penelitian menjadi berkurang.

2. Banyak perusahaan yang terdaftar di BEI yang tidak menyajikan data laporan tahunan, khususnya pengungkapan jumlah rapat komite audit secara lengkap dan jelas.

3. Penelitian ini hanya berpusat pada perusahaan yang terdaftar di BEI.

Rekomendasi yang dapat dijadikan pertimbangan untuk penelitian sebidang di masa yang akan datang adalah penambahan sampel penelitian, baik dengan memperluas tahun pengamatan maupun melakukan perbandingan antara dua negara atau lebih. Penelitian selanjutnya juga diharapkan dapat menambahkan variabel lain dan menggunakan cara pengukuran yang berbeda untuk setiap variabel yang telah diuji.

\section{DAFTAR PUSTAKA}

Abarbanell, J. S., \& Bushee, B. J. (1998). Abnormal returns to a fundamental analysis strategy. The Accounting Review, 73 (1), 19-45.

Adebiyi, W. K., \& Olowookere, J. K. (2016). Ownership structure and the quality of financial reporting: Evidence from Nigerian Deposit Money Banks. International Journal of Economics, Commerce, and Management, 4 (1), 541-552. ISSN: 2348-0386.

Al-Fayoumi, N., Abuyazed, B., \& Alexander, D. (2006). Ownership structure and earnings management in emerging markets: The case of Jordan. International Research Journal of Finance and Economics, 38, 14502887.

Alaryan, L. A. (2015). Relationship between ownership structure and earnings quality. Basic Research Journal of Business Management and Account, 4 (8), 200-205. ISSN: 23156899.

Ali, S. M., Salleh, N. M., \& Hassan, M. S. (2008). Ownership structure and earnings management in Malaysian listed companies: The size effect. Asian Journal of Business and Accounting, 1 (2), 89-116.

Alkdai, H. K. H., \& Hanefah, M. M. (2012). Audit committee characteristics and earnings management in Malaysian shariah compliant companies. Business and Management Review, 2 (2), 52-61. ISSN: 2047-0398.

Alkhatib, K. (2012). The determinants of leverage of listed companies. International Journal of Business and Social Science, 3 (24), 54-59.

Alsharairi, M., \& Salama, A. (2012). Does high leverage impact earnings management? Evidence from non-cash mergers and acquisitions. Journal of Financial and Economic Practice, 12 (1), 17-33 .

Alzoubi, E. S. S. (2015). Ownership structure and earnings management: Evidence from Jordan. International Journal of Accounting \& Information Management, 24 (2), 135-161.

Alves, S. (2012). Ownership structure and earnings management: Evidence from Portugal. Australian Accounting, Business, and Finance Journal, 6 (1), 57-74.

Ardison, K. M. M., Martinez, A. L., \& Galdi, F. C. (2012). The effect of leverage on earnings management in Brazil. Advances in Scientific and Applied Accounting, vol 5 (3), 305-324. ISSN: 1983-8611.

Ayemere, I. L., \& Elijah, A. (2015). Audit committee attributes and earnings management: Evidence from Nigeria. International Journal of Business and Social Research, 5 (4), 14-23.

Aygun, M., Ic, S., \& Sayim, M. (2014). The effects of corporate ownership structure and board size on earnings 
management: Evidence from Turkey. International Journal of Business and Management, 9 (12), 123-132. ISSN: 1883-8119.

Ariefianto, M. D. (2012). Ekonometrika esensi dan aplikasi dengan menggunakan eviews. Jakarta: PT. Gelora Aksara Pratama.

Bagheri, S. M. B., Emamgholipur, M., Bagheri, M., \& Rekabdarkolaei, E. A. (2013). Effect of accounting conservatism level, debt contracts, and profitability on the earnings management of companies: Evidence from Tehran Stock Exchange. International Journal of Economy, Management, and Social Sciences, 2 (7), 533-538. ISSN: 2306-7276.

Banimahd, B., \& Aliabadi, M. J. (2013). A study on relationship between earnings management and operating cash flow management: Evidence from Tehran Stock Exchange. Management Science Letter, 3 (6), 16-77.

Ben-Nasr, H., Boubakri, N., \& Cosset, J. (2015). Earning quality in privatized firms: The role of state and foreign owners. J. Account. Public Policy, 123.

Bergstresser, D., \& Phillipon, T. (2006). CEO incentives and earnings management. Journal of Financial Economics, 511-529.

Blue Ribbon Committee. (1999). Improving the effectiveness of corporate audit committees. Stamford, CT: BRC.

Bukit, R. B., \& Iskandar, T. M. (2009). Surplus free cash flow, earnings management, and audit committee. Int. Journal of Economics and Management, Vol. 3 (1), 204-223. ISSN: $1823-836 \mathrm{X}$.

Bushee, B. J. (1998). The influence of institutional investors on myopic R\&D investment behavior. The Accounting Review.

Bushman, R., Chen, Q., Engel, E., \& Smith, A. (2004). Financial accounting information, organizational complexity, and corporate governance systems. Journal of Accounting and Economics, 37, 167-201.

Chandrasegaram, R., Rahimansa, M. R., Rahman, S. K. A., Abdullah, S., \& Mat, N. N. (2013). Impact of audit committee characteristics on earnings management in Malaysian public listed companies. International Journal of Finance and Accounting, 2 (2), 114119.

Christie, A. A., \& Zimmerman, J. L. (1994). Efficient and opportunistic choices of accounting procedures: corporate control contests. The Accounting Review, 69 (4), 539-566.

Chtourou, S. M., Bedard, J., \& Courteau, L. (2001). Corporate governance and earnings management. Retrieved from http://papers.ssrn.com/abstract=275053

Chung, R., Firth, M., \& Kim, J. (2005). Earnings management, surplus free cash flow, and external monitoring. Journal of Business Research, 58, 766776.

Dahlquist, M., \& Robertsson, G. (2001). Direct foreign ownership, institutional investors, and firm characteristics. Journal of Financial Economics, 413440.

Davidson, R., Stewart-Goodwin, J., \& Kent, P. (2005). Internal governance structures and earnings management. Accounting and Finance, 241-267.

Dechow, P. M., \& Skinner, D. J. (2000). Earnings management: Reconciling the views of accounting academics, practitioners, and regulators. Accounting Horizons, 14 (2), 235-250.

DeFond, M. L., \& Park, C. W. (1997). Smoothing income in anticipation of future earnings. Journal of Accounting \& Economics, 115-139.

DeGeorge, F., Patel, J., \& Zeckhauser, R. (1999). Earnings management to exceed threshold. The Journal of Business, 72 (1).

Denis, D. K., \& McConnell, J. J. (2003). International corporate governance. 
ECGI Working Paper Series in Finance, 1-56.

Dimitropoulus, P. E., \& Asteriou, D. (2010). Accounting relevance and speculative intensity: Empirical evidence from Greece. Journal of Applied Accounting Research, (3), 195212.

Emamgholipur, M., Bagheri, S. M. B., Mansourinia, E., \& Arabi, A. M. (2013). A study on relationship between institutional investors and earnings management: Evidence from the Tehran Stock Exchange. Management Science Letter 3, 11051112.

Forum for Corporate Governance in Indonesia. (2002). Peranan dewan komisaris dan komite audit dalam pelaksanaan corporate governance (tata kelola perusahaan). Jakarta: Author.

Ghozali, I. (2011). Aplikasi analisis multivariate dengan program IBM SPSS 19. Semarang: Universitas Dipenegoro.

Gill, A., Biger, N., \& Mathur, M. (2011). The effect of capital structure on profitability: Evidence from the United States. International Journal of Management, 28 (4).

Gore, P., Pope, P., \& Singh, A. (2001). Non-audit services, auditor independence, and earnings management. Retrieved from http:// eprints.lancs.ac.uk/48611/.

Greco, G. (2012). Ownership structures, corporate governance, and earnings management in European oil industry. Retrieved from https://papers.ssrn.com/ sol3/papers.cfm?abstract_id=2015590.

Gujarati, D. (2003). Ekonomi dasar. Jakarta: Erlangga.

Gulzar, M. A., \& Wang, Z. (2011). Corporate governance characteristics and earnings management: Empirical evidence from Chinese listed firms. International Journal of Accounting and Financial Reporting, 1 (1), 133 151. ISSN: 2162-3082.
Guo, F., \& Ma, S. (2015). Ownership characteristics and earnings management in China. The Chinese Economy: Translation and Studies, 48 (5), 372-395.

Habbash, M. (2011). The role of corporate governance regulations in constraining earnings management practice in Saudi Arabia. Retrieved from http://www.fbe. uaeu.ac.ae/en/csafc/pdf/ad_58.pdf.

Hamza, T., \& Lakhal, F. (2010). The determinants of earnings management by the acquirer: The case of French corporate takeovers. Laboratoire Orleanais De Gestion, 1-25.

Hassan, S. U., \& Ahmed, A. (2012). Ownership structure and opportunistic accounting: A case of listed food and beverage firms in Nigeria. International Journal of Phsycal and Social Sciences, 2(7), 236-256. ISSN: 2249-5894.

Healy, P. M. (1985). The effect of bonus schemes on accounting decisions. Journal of Accounting and Economics, 7 (1), 85-107.

Healy, P. M., \& Wahlen, J. M. (1999). A review of the earnings management literature and its implication for standard setting. Accounting Horizon, 13 (4), 365-383.

Hepworth, S. R. (1953). Smoothing periodic income. The Accounting Review, 28 (1), 32-39.

Indriantoro, N., \& Supomo, B. (2013). Metodologi penelitian bisnis (edisi 1). Yogyakarta: BPFE.

Ioualalen, L., Khemakhem, H., \& Fontaine, R. (2015). The impact of audit committee characteristics on earnings management: A Canadian case study. Case Studies in Business and Management, 2 (1), 78-96. ISSN: 2333-3324.

Isenmila, P. A., \& Elijah, A. (2012). earnings management and ownership structure: Evidence from Nigeria. Research Journal of Finance and Accounting, 3 (7). ISSN: 2222-2847. 
Ishak, I., Haron, M. N., Salleh, N. M. Z. N., \& Rashid, A. A. (2011). Family control and earnings management: Malaysia evidence. Retrieved from http://www.ipedr.com/vol22/16ICEBM2011-M00029.pdf.

Ismail, W. A. W., Dunstan, K., \& Zijl, T. V. (2009). Earnings quality and corporate governance following the implementation of Malaysian code of corporate governance. Retrieved from https://www.researchgate.net/publicatio $\mathrm{n} / 228121833$.

Itturriaga, F. J. L., \& Hoffmann, P. S. (2005). Earnings management and internal mechanisms of corporate governance: Empirical evidence from Chilean Firms. Corporate Ownership \& Control, 3 (1), 17-29.

Jensen, M. C., \& Meckling, W. H. (1976). Theory of firm: Managerial behavior, agency costs, and ownership structure. Journal of Financial Economics, 3 (4), 305-360.

Jiang, W., Lee, P., \& Anandarajan, A. (2008). The association between corporate governance and earnings quality: Further evidence using govscore. Advances in Accounting, 191201.

Johari, N. H., Saleh, N. M., Jaffar, R., \& Hassan, M. S. (2008). The influence of board independence, competency, and ownership on earnings management in Malaysia. Int. Journal of Economics and Management, 2 (2), 281-306. ISSN: 1823-836X.

Jones, J. (1991). Earnings management during import relief investigations. Journal of Accounting Research, 29 (2), 193-228.

Keputusan Ketua Badan Pengawas Pasar Modal dan Lembaga Keuangan Nomor: KEP-643/BL/2012. Pembentukan dan pedoman pelaksanaan kerja komite audit. 7 Desember 2012. Retrieved from http://www.sampoerna.com/id_id /investor_information/capital_market_r egulation/documents/peraturan\%20ix.i. $5 \% 20$ pembentukan $\% 20$ dan\%20pedom an\%20pelaksanaan\%20kerja\%20komit e\%20audit.pdf.

Khomsiyah. (2005). Analisis hubungan struktur dan indeks corporate governance dengan kualitas pengungkapan. Retrieved from http://etd.repository.ugm.ac.id/index.ph $\mathrm{p}$ ?mod=penelitian_detail\&sub=Peneliti anDetail\&act $=$ view\&typ $=h t m l \& b u k u \_i$ $\mathrm{d}=31527$.

Kouki, M., Elkhadi, A., Atri, H., \& Souid, S. (2011). Does corporate governance constrain earnings management? Evidence from U.S firms. European Journal of Economics, Finance, and Administrative Sciences. ISSN: 14502275.

Li, Y., Liu, J., \& Eddie, I. (2011). Share types and earnings management: Evidence from Chinese listed companies. Corporate Ownership \& Control, 8 (2), 271-284.

Lin, P., Hutchinson, M., \& Percy, M. (2009). Can an effective audit committee help to mitigate earnings management in Chinese firms listed in Hong Kong?. Retrieved from http://eprints.qut.edu.au/38099/.

Lobo, G. J., \& Zhou, J. (2006). Did conservatism in financial reporting increase after the Sarbanes-Oxley act? Initial evidence. Accounting Horizons, 20 (1), 57-73.

Loomis, C. J. (1999, August 2). Lies, damned lies, and managed earnings. Fortune, 140 (2), 74-92.

Luo, M. (2008). Unusual operating cash flow and stock returns. J. Account Public Policy, 420-429.

McClave, J. T., \& Sincich, T. L. (2003). Statistics. New Jersey: Person Education, Inc.

McDaniel, L., Martin, R. D., \& Maines, L. A. (2002). Evaluating financial reporting quality: The effects of financial expertise vs financial literacy. The Accounting Review, 77, 139-167.

McNichols, M. F. (2000). Research design issues in earnings management studies. 
Journal of Accounting and Public Policy 19, 313-345.

Meek, G. K., Roberts, C. B., \& Gray, S. J. (1995). Factors influencing voluntary annual report disclosures by U.S, U.K, and continental European multinational corporations. Retrieved from https://www.jstor.org/stable/155561.

Mutiwero, M. (2014). Pengaruh komite audit terhadap manajemen laba (studi pada industri manufaktur yang terdaftar di BEI). Retrieved from http:// repository.unhas.ac.id/handle/1234567 89/10751.

Menon, K., \& Williams, J. D. (1994). The use of audit committees for monitoring. The Accounting Review, 79 (4), 10951118.

Min, C. (2015). Chinese state controlling, institutional participation, and real earnings management. International Journal of Economics and Finance, 7 (9), 255-266. ISSN: 1916-9728.

Mitani, H. (2010). Additional evidence on earnings management and corporate governance. Financial Research and Training Center Discussion Paper Series, 1-22.

Morck, R., Shleifer, A., \& Vishny, R. W. (1988). Management ownership and market valuation: An empirical analysis. Journal of Financial Economics, 20, 293-315.

Nelwan, M. L., \& Tansuria, B. I. (2014). The effectiveness of audit committee independence and expertise to prevent earnings management practices in Indonesian listed manufacturing companies. Retrieved from www.multiparadigma.lecture.ub.ac.id.

Nuswantara, D. A. (2004). The effect of market share and leverage interaction toward earnings management practices. Retrieved from http://pdeb.fe.ui.ac.id/ $? \mathrm{p}=6848$.

Niri, N. N., Moeinaddin, M., \& Heyrani, F. (2014). An investigation of the relationship between type of ownership, audit quality, and earnings management of listed companies in
Tehran Stock Exchange. Interdisciplinary Journal of Contemporary Research in Business, 5 (11), 202-210.

Poli, S. (2015). Do ownership structure characteristics affect Italian private companies' prospensity to engage in practices of "earnings minimization" and "earnings change minimization"? International Journal of Economics and Finance, 7 (6), 193-207. E-ISSN: 1916-9728.

Prayogo, M. M. V., Feliana, Y. K., \& Sutanto, A. C. C. (2013). Financial condition moderated the effectiveness of audit committee to reduce earnings management. Retrieved from http://repository.ubaya.ac.id/24057/1.

Qallap, K. D. H. (2014). Earnings management in Jordanian public shareholding service companies and influential factors. Research Journal of Finance and Accounting, 5 (12), 70-81. ISSN: 2222-2847.

Rao, S. N., \& Dandale, S. (2008). Earnings management and performance of Indian equity rights issues. Retrieved from http://ssrn.com/abstract=1155027.

Saleh, N. M., Iskandar, T. M., \& Rahmat, M. M. (2007). Audit committee characteristics and earnings management: Evidence from Malaysia. Asian Review of Accounting, 15 (2), 147-163.

Salihi, A. A., \& Jibril, R. S. (2015). The effect of board the size and audit committee the size on earnings management in Nigerian consumer industries companies. International Journal of Innovative Research and Development. ISSN: 2278-0211.

Salleh, N. M. Z. N., \& Haat, M. H. C. (2014). Audit committee and earnings management: Pre and post MCCG. International Review of Management and Business Research, 3 (1), 307-318. ISSN: 2306-9007.

Schipper, K. (1989). Commentary on earnings management. Accounting Horizon, 3 (4), 91-102. 
Siam, Y. A., Laili, N. H. B., \& Khairi, K. F. (2015). The relationship between audit committee characteristics and earnings management among Jordanian listed companies: Proposing conceptual framework. Research Journal of Finance and Accounting, 6 (18), 1-10. ISSN: 2222-2847.

Singh, M., \& Davidson, W. N. (2003). Agency costs, ownership structure, and corporate governance mechanisms. Journal of Banking and Finance, 27, 793-816.

Singhvi, S. S., \& Desai, Harsha, B. (1971). An empirical analysis of the quality of corporate financial disclosure. Retrieved from http://connection.ebsco host.com/c/articles/4482572/empiricalanalysis-quality-corporate-financialdisclosure.

Soliman, M. M., \& Ragab, A. A. (2014). Audit committee effectiveness, audit quality, and earnings management: An empirical study of listed companies in Egypt. Research Journal of Finance and Accounting, 5 (2), 155-166. ISSN: 2222-2847.

Stulz, R. M. (1999). Globalization of equity market and the cost of capital. Journal of Applied Corporate Finance, 12 (3).

Sun, J., Liu, G., \& Lan, G. (2011). Does female directorship on independent audit committees constrain earnings management?. Journal of Business Ethics, 99 (3), 369-382.

Sun, L., \& Rath, S. (2010). Earnings management research: A review of contemporary research methods. Global Review of Accounting and Finance, 1 (1), 121-135.

Teshima, N., \& Shuto, A. (2008). Managerial ownership and earnings management: Theory and empirical evidence from Japan. Journal of International Financial Management \& Accounting, 19 (2), 1-37.

Thoopsamut, W., \& Jaikengit, A. (2008). The relationship between audit committee characteristics, audit firm size, and earnings management in quarterly financial reports of companies listed in the stock exchange of Thailand. Retrieved from http://connection.ebscohost.com/c/artic les.

Wang, Y., \& Campbell, M. (2012). Corporate governance, earnings management, and IFRS: Empirical evidence from Chinese domestically listed companies. Advances in Accounting, incorporating Advances in International Accounting, 189-192.

Warfield, T. D., Wild, J. J., \& Wild, K. L. (1995). Managerial ownership, accounting choices, and informativeness of earnings. Journal of Accounting and Economics, 20 (1), 6191.

Watts, R. L., \& Zimmerman, J. L. (1978). Towards a positive theory of determination of accounting standards. Accounting Review, 53 (1), 112-134.

Watts, R. L., \& Zimmerman, J. L. (1990). Positive accounting theory: A ten year perspective. The Accounting Review, 65 (1), 131-156.

Yang, C., Lai, H., \& Tan, B. L. (2008). Managerial ownership structure and earnings management. Journal of Financial Reporting and Accounting, 6 (1), 35-53.

Yoon, S. S., \& Miller, G. A. (2002). Cash from operations and earnings management in Korea. The International Journal of Accounting, 37, 395-412.

Yusof, M. A. M. (2010). Does audit committee constraint discretionary accruals in MESDAQ listed companies?. International Journal of Business and Social Science, 1 (3), 124-136. 
Yyuliawati (2004, November 11). Komite audit Indofarma terima keputusan Bapepam. Tempo Interaktif. Retrieved from https://bisnis.tempo.co/read/news/ 2004/11/11/05651010/komite-auditindofarma-terima-keputusan-bapepam. 